\title{
28. HYDROCARBON GASES IN CANNED CORE SAMPLES FROM LEG 28 SITES 271, 272, AND 273, ROSS SEA
}

\author{
Richard D. McIver, Esso Production Research Company, Houston, Texas
}

\section{INTRODUCTION}

Samples from the Ross Sea cores are among the richest yet analyzed for hydrocarbon gases; and they contain small but significant amounts of ethane and heavier gaseous hydrocarbons. The gas was anticipated because of shipboard observations of its presence. This observation also was responsible for the greater sampling density, particularly at Site 272 .

As in previous cases the samples were collected soon after recovery and sealed in ordinary size $2 \frac{1}{2}$ tin cans. Upon receipt at the laboratory, 21 cans were chosen for these analyses. A few of the cans had already begun leaking-evidenced by salt incrustation and corrosion at one or more points along the edges of the lid. Some of these leaking cans were found to contain virtually no hydrocarbon gas, so each can was carefully inspected, and the few bad ones were set aside.

The' selected cans were punctured through a rubber septum clamped tightly to their sides. A measured volume of each can's air space was removed with a hypodermic syringe and introduced into the inlet system of a Perkin-Elmer Model $154 \mathrm{~B}$ gas chromatograph with a hydrogen-flame detector. The column is a 2-meter P.E. column B (di-2-ethylhexyl sebacate); temperature, $46^{\circ} \mathrm{C}$; helium pressure, $8 \mathrm{psig}$; hydrogen pressure, $8 \mathrm{psig}$.
From the volume of gas and sediment in the cans, and the gas chromatographic results, the gas contents were calculated as parts per million of gas by volume (i.e., mls of gas at STP per $10^{6} \mathrm{mls}$ of sediment as received). After gas-space samples were run in duplicate, the cans were opened and a sample of sediment was removed and agitated with water in a Waring blender to remove any gas remaining in the sticky mud. The gravities were so small (a few ppm of methane at most), that after the first few samples only the can's free (gas-space) gas was analyzed subsequently.

\section{RESULTS AND DISCUSSION}

Results of organic carbon and gas determinations are listed in Table 1. They are also compared, diagrammatically, with all samples run previously, by the histograms in Figures 1 and 2. Overall, muds from Holes 272 and $273 \mathrm{~A}$ have more gas than any other samples run to date; that is, there is more residual gas remaining in the cans with them, on the average, than with samples from any other suite. They are more consistently high in value than Site 186 (McIver, 1973) that had one value of $216,700 \mathrm{ppm}$ of methane. Site 229 (McIver, 1974) had one sample with $165,000 \mathrm{ppm}$ methane, but the second was $84,500 \mathrm{ppm}$. Only two

TABLE 1

Analytical Results - Leg 28 Samples

\begin{tabular}{|c|c|c|c|c|}
\hline $\begin{array}{c}\text { Sample } \\
\text { (Interval in } \mathrm{cm} \text { ) }\end{array}$ & $\begin{array}{l}\text { Organic } \\
\text { Carbon } \\
\text { (\% by wt) }\end{array}$ & $\begin{array}{l}\text { Total Hydro- } \\
\text { carbon Gas } \\
\text { (ppm by vol.) }\end{array}$ & $\begin{array}{c}\text { Ethane and } \\
\text { Heavier HC Gas } \\
\text { (ppm by vol.) }\end{array}$ & $\begin{array}{c}\text { Ratio, Total } \\
\text { HC Gas to } \\
\text { Ethane + }\end{array}$ \\
\hline $271-24-2,50-70$ & 0.25 & 3,700 & 111 & 33 \\
\hline $272-7-2,140-150$ & 0.53 & 15,900 & 71 & 224 \\
\hline $272-8-1,0-20$ & 0.32 & 26,900 & 113 & 238 \\
\hline $272-10-4,0-10$ & 0.36 & 68,000 & 138 & 492 \\
\hline $272-13-3,0-10$ & 0.38 & 38,900 & 131 & 297 \\
\hline $272-14-4,0-6$ & 0.46 & 115,000 & 76 & 1513 \\
\hline $272-18-1,143-150$ & 0.43 & 50,400 & 62 & 813 \\
\hline $272-21-5,144-150$ & 0.44 & 29,500 & $\operatorname{tr}$ & $>1400$ \\
\hline $272-23-3,140-150$ & 0.46 & 170,300 & 177 & 962 \\
\hline $272-27-2,137-144$ & 0.41 & 145,100 & 274 & 529 \\
\hline $272-29-2,140-150$ & 0.39 & 75,500 & 100 & 686 \\
\hline $272-31-1,0-5$ & 0.39 & 179,000 & 58 & 3086 \\
\hline $272-33-2,0-8$ & 0.41 & 54,000 & tr & $>2700$ \\
\hline $272-39-1,0-5$ & 0.76 & 27,700 & 38 & 728 \\
\hline $273 \mathrm{~A}-11-4,140-150$ & 0.47 & 52,000 & 90 & 578 \\
\hline $273 \mathrm{~A}-13-4,140-150$ & 0.51 & 73,000 & 716 & 102 \\
\hline $273 A-14-2,6-16$ & 0.46 & 132,000 & 112 & 1179 \\
\hline $273 \mathrm{~A}-16-2,0-7$ & 0.47 & 147,000 & 876 & 168 \\
\hline $273 \mathrm{~A}-17-2,140-150$ & 0.45 & 111,200 & 88 & 1263 \\
\hline $273 \mathrm{~A}-22-2,143-150$ & 0.05 & 136,000 & 636 & 214 \\
\hline $273 \mathrm{~A}-25-2,144-150$ & 0.38 & 60,000 & 77 & 787 \\
\hline
\end{tabular}




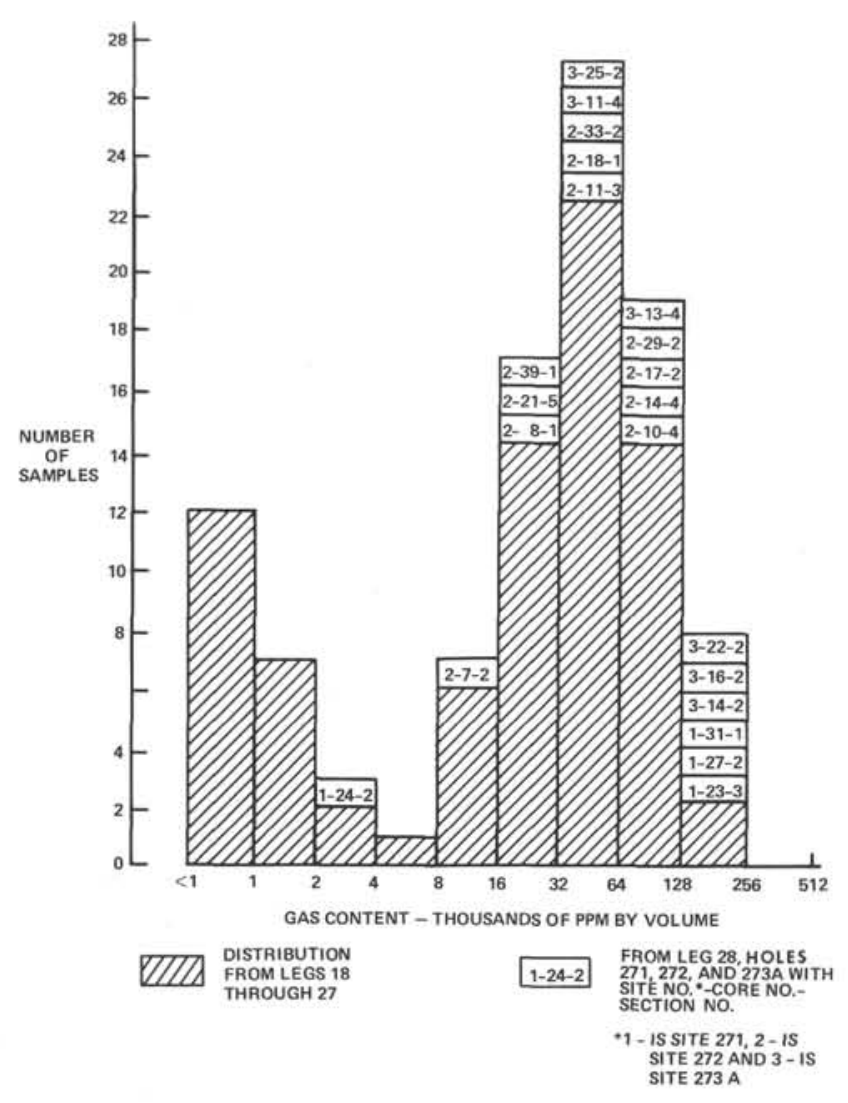

Figure 1. Residual hydrocarbon gas contents of Leg 28 samples compared with preceding legs.

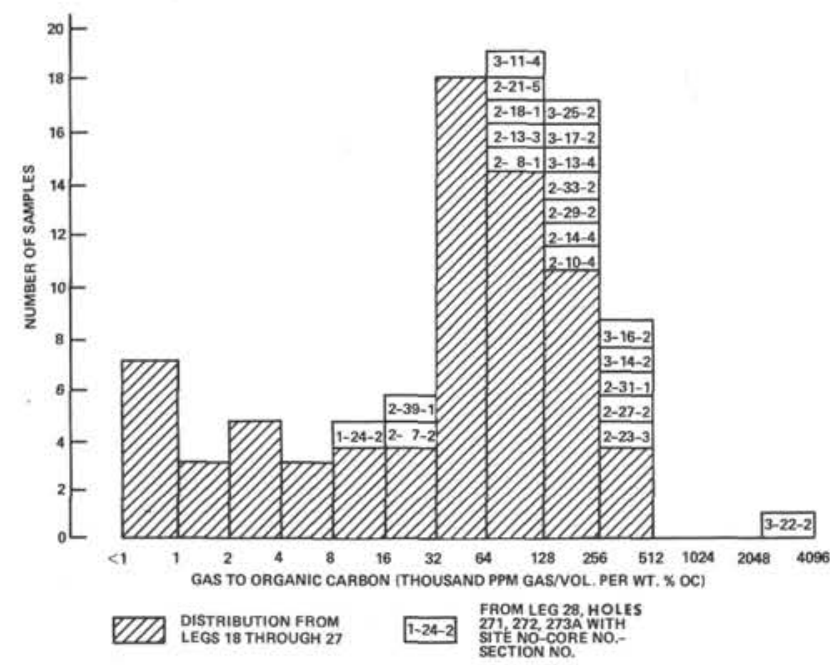

Figure 2. Hydrocarbon gas as a function of organic carbon contents - Leg 28 compared with previous results.

samples were sent from this location so we cannot say anything about uniformity of methane contents down the hole.

Perhaps even more important is the small but significant quantity of ethane and higher homologs appearing in some of these gases, particularly those from Hole
273A. In all samples from previous suites of canned cores, the amount of ethane-plus was generally very low. The background of a procedure is of the order of 20 ppm and seldom until this suite did more appear. (A few notable exceptions are tabulated in Table 2.) Ethane is generally attributed to thermal diagenesis, or maturation, of organic matter at depth, and in DSDP cores may be considered as evidence that somewhere in the vicinity, more deeply buried rocks are already experiencing the early stages of thermal cracking that leads to the generation of light hydrocarbons (Mclver, 1972).

Generally in the DSDP, the ratio of hydrocarbon gas to its heavier homologs in the canned gases was greater than 1000 and often at least 3000 or 4000 . If this is "background", then lower ratios may be evidence of local organic diagenesis. The erratic values of this ratio, from 200 to 3000 at Site 272, suggests irregular dilution of the methane gas from migrating ethane. The generally lower values (100-1200) at Site 273A suggest more abundant generation and migration. And the value, 33, at Site 271 is evidence of very extensive ethane generation and migration. These ratios are generally lower, but ranked in the same order as virtually the same ratio, methane to $\mathrm{C}_{2} \mathrm{H}_{6}$, determined onboard Glomar Challenger on samples taken from gas "gaps" in the core, observed through the core liner. The values thus obtained were 75 and 88 for Site 271, 2000 to 3000 at Site 272 , and 500 to 700 at Site 273A. The differences between results from the two analog sites may be attributed to different methods including the timing of collecting the samples. Those provided us had probably bled off their gas for longer periods and there may have been a more rapid (or preferential) release of methane, particularly if the gases were immobilized as hydrates at these sites.

TABLE 2

Ethane + Contents of Residual, Canned Gases in Excess of 50 ppmv of Total Cuttings

\begin{tabular}{|c|c|c|c|c|c|c|}
\hline Leg & Site & Core & Section & $\begin{array}{l}\text { Ethane + } \\
\text { Content } \\
\text { (ppmv) }\end{array}$ & $\begin{array}{l}\text { Total } \\
\text { HC Gas } \\
\text { (ppmv) }\end{array}$ & $\begin{array}{l}\text { Ratio, total } \\
\text { HC Gas } \\
\text { to Ethane + }\end{array}$ \\
\hline 18 & $174 \mathrm{~A}$ & 15 & 4 & 122 & 24,300 & 199 \\
\hline 18 & $174 \mathrm{~A}$ & 40 & 5 & 209 & 41,400 & 198 \\
\hline 18 & 176 & (none) & & & & $>1000$ \\
\hline 18 & 180 & (none) & & & & $>1000$ \\
\hline 19 & 185 & (none) & & & & $>1000$ \\
\hline 19 & 186 & (none) & & & & \\
\hline 19 & 189 & (none) & & & & \\
\hline 19 & 191 & (none) & & & & \\
\hline 21 & 204 & (none) & & & & $>1000$ \\
\hline 21 & 210 & (none) & & & & \\
\hline 23 & 222 & (none) & & & & $>1000$ \\
\hline 23 & 229 & (none) & & & & \\
\hline 23 & $229 \mathrm{~A}$ & (none) & & & & \\
\hline 24 & 231 & 13 & 4 & 78 & 42,000 & 538 \\
\hline 24 & 231 & 13 & 5 & 95, & 67,000 & 705 \\
\hline 24 & 231 & 16 & $4 / 5$ & $246^{\prime}$ & 62,600 & 254 \\
\hline 24 & 232 & (none) & & & & \\
\hline 27 & 262 & (none) & & & & $>3000$ \\
\hline 28 & \multicolumn{6}{|c|}{ (see Table 1) } \\
\hline
\end{tabular}


That these samples from Holes 271, 272, and 273A are very gassy is also evidenced by their gas contents as a function of their organic carbon contents. As Figure 2 shows, these samples have more gas per percent organic carbon, on the average, than the samples from the other 15 sites sampled to date. The samples have only moderate amounts of organic matter; but whether the nature of the organic matter is different; i.e., more susceptible to bacterial attack than the commonly found type; or whether this abundance simply reflects more intensive migration, cannot be determined. It appears that this would be a very interesting area for more extensive organic geochemical studies.

\section{ACKNOWLEDGMENTS}

The author thanks Ralph Pokluda and Harvey Fry who assisted with the analyses; and Esso Production Research
Company for their continuing support of research on DSDP cores, and for their permission to publish this report.

\section{REFERENCES}

McIver, R.D., 1972. Geochemical significance of gas and gasoline-range hydrocarbons and other organic matter in a Miocene sample from Site 134-Balearia abyssal plain. In Ryan, W.B.F., Hsu, K.J., et al., Initial Reports of the Deep Sea Drilling Project, Volume 13: Washington (U.S. Government Printing Office), p. 813-817.

McIver, R.D., 1973. Hydrocarbons in canned muds from Sites 185, 186, 189 and 191-Leg 19. In Creager, J.S., Scholl, D.W., et al., Initial Reports of the Deep Sea Drilling Project, Volume 19: Washington (U.S. Government Printing Office), p. 875-878.

McIver, R.D., 1974. Residual gas contents of organic-rich canned sediment samples from Leg 23. In Whitmarsh, R.B., Weser, O.E., et al., Initial Reports of the Deep Sea Drilling Project, Volume 23: Washington (U.S. Government Printing Office), p. 971-973. 